\title{
Purifikasi Parsial Enzim Ekstraseluler (Anoxybacillus sp.) yang Diisolasi dari Sumber Air Panas Bukit Kili Solok serta Aplikasinya untuk Menghidrolisis Limbah Berserat
}

\author{
Zona Octarya $^{\left.1^{*}\right)}$, Sumaryati Syukur ${ }^{2)}$,Endang Purwati ${ }^{3)}$ \\ ${ }^{1)}$ Program Studi Pendidikan Kimia, Fakultas Tarbiyah dan Keguruan \\ Universitas Islam Negeri Sultan Syarif Kasim Riau \\ ${ }^{2)}$ Program Studi Kimia, Fakultas MIPA Universitas Andalas, Padang \\ ${ }^{3)}$ Program Studi Teknologi Hasil Ternak, Fakultas Peternakan Universitas Andalas, Padang
}

Diterima 11-12-2012 Disetujui 25-11-2013

\begin{abstract}
Termostable enzyme from thermophilic bacteria is very potential to improve technical enzyme in industry which used high temperature. High water temperature exerts selection pressure on microbial species leading to specific flora that survives and tolerates heat stress. The relative isolation and unique physical properties of Bukit Kili Ketek Hot Springs in Solok, West Sumatera may yield unique thermophiles. The generation of extracellular enzymatic bacterial is highly desirable for production of hydrolitic enzymes, which are useful in various industrial application and in animal feeds. This study, conducted to purify extracellular enzymes from thermophilic bacteria (Anoxybacillus $\mathrm{sp}$.). This bacteria was isolated in Bukit Kili Ketek Hot Springs, and after identified by analysis of $16 \mathrm{~S}$ rRNA gene, 97\% of similiarty with Anoxybacillus sp. was of obtained. The temperature of the hot waters was $52^{\circ} \mathrm{C}$ and the $\mathrm{pH}$ was 8 . Extracellular and hydrolytic enzyme production were screened by qualitative SDS-PAGE method. SDS-PAGE analysis gave protein bands at $\pm 110 \mathrm{kDa}, \pm 80 \mathrm{kDa}$, $\pm 60 \mathrm{kDa}, 50 \mathrm{kDa}, 25 \mathrm{kDa}$, and $\pm 10 \mathrm{kDa}$, respectively. Extracellular enzymes were used to degrade cellulose waste. The cellulose activity for degradation of baggasse and pineapple pulp was $0,451 \mathrm{IU} / \mathrm{mL}$ and $0,310 \mathrm{IU} / \mathrm{mL}$ at $50^{\circ} \mathrm{C}$ and $\mathrm{pH} 6$.
\end{abstract}

Keywords: Anoxybacillus sp, cellulose waste, hot water, hydrolytic enzymes, thermophilic bacteria

\begin{abstract}
ABSTRAK
Enzim termostabil dari bakteri termofilik merupakan enzim yang sangat potensial untuk mengatasi kendala teknis industri yang berhubungan dengan proses pada suhu tinggi. Salah satu sumber enzim adalah mikroorganisme termofilik yang banyak terdapat pada sumber air panas. Indonesia merupakan negara kepulauan yang banyak mempunyai sumber air panas, salah satunya adalah Kabupaten Solok. Setelah dilakukan isolasi dan identifikasi bakteri termofilik dengan analisis Gen 16S rRNA, didapatkan bahwa 97\% bakteri ini memiliki kesamaan dengan Anoxybacillus sp. Penelitian ini mencakup purifikasi ekstrak enzim kasar bakteri termofilik (Anoxybacillus sp.) dari sumber air panas Bukit Kili Ketek di Kabupaten Solok. Suhu air panas adalah $52^{\circ} \mathrm{C}$ dan $\mathrm{pH}$ air adalah 8 . Dari hasil SDS PAGE, ekstrak enzim kasar yang diperoleh adalah \pm 110 $\mathrm{kDa}, \pm 80 \mathrm{kDa}, \pm 60 \mathrm{kDa}, 50 \mathrm{kDa}, 25 \mathrm{kDa}$ dan $\pm 10 \mathrm{kDa}$. Ekstrak enzim kasar ini diaplikasikan untuk menghidrolisis limbah berserat yaitu ampas tebu dan limbah nenas. Aktivitas enzim selulase paling tinggi adalah $0,451 \mathrm{IU} / \mathrm{mL}$ terhadap ampas tebu dan $0,310 \mathrm{IU} / \mathrm{mL}$ terhadap ampas nenas pada suhu $50^{\circ} \mathrm{C}$ dan $\mathrm{pH} 6$.
\end{abstract}

Kata Kunci: air panas, Anoxybacillus sp., bakteri termofilik, enzim hidrolitik, limbah berserat

*Telp: +6285274711954

Email: souvenirznoc@yahoo.co.id 


\section{PENDAHULUAN}

Indonesia memiliki banyak sumber air panas yang potensial dan unik. Sumber air panas yang ada di Kabupaten Solok sudah dikembangkan sebagai objek wisata dan tempat pemandian, namun belum digali sebagai sumber mikroorganisme termofilik. Kabupaten Solok adalah daerah Provinsi Sumatera Barat yang dilalui oleh Pegunungan Bukit Barisan. Gunung Talang adalah salah satu gunung berapi di Kabupaten Solok yang banyak dijumpai sumber air panas. Lingkungan ini merupakan habitat semua bakteri termasuk di antaranya bakteri termofilik. Beberapa sumber air panas yang ada di daerah Solok berpotensi untuk diketahui keanekaragaman hayati bakteri termofiliknya. Selanjutnya keanekaragaman jenis bakteri termofilik tersebut perlu digali sifat-sifat dan potensi kegunaannya bagi kehidupan manusia terutama dalam bidang teknologi dan industri. Dalam hal ini yang sangat penting adalah untuk mengetahui jenis bakteri yang potensial dan upaya untuk mengeksplorasinya.

Belum ada yang melaporkan penelitian mikroorganisme termofilik sumber air panas di Kabupaten Solok, sedangkan sumber air panas sangat banyak di Kabupaten Solok, diantaranya yaitu Sumber Air Panas Bukit Kili Barat, Sumber Air Panas Bukit Kili Ketek, Sumber Air Panas Sapan dan Sumber Air Panas Bukik Gadang. Semua sumber air panas tersebut mempunyai potensi sebagai sumber mikroorganisme termofilik. Air Panas Bukit Kili Ketek adalah salah satu sumber air panas yang belum ada digali potensi mikroorganismenya.

Penelitian sebelumnya mengemukakan bahwa produksi enzim hidrolitik dan ekstraseluler (amilase, lipase, dan gelatinase) bakteri ditapis dengan metode kultur streak bakteri termofilik murni pada nutrient starch agar (NSA), nutrient gelatine agar (NGA), dan nutrient lipid agar (NLA) melalui pengukuran zona bening (Narayan et al. 2008). Produktivitas enzim termostabil yang berasal dari isolat bakteri yang lebih potensial dipengaruhi oleh $\mathrm{pH}$, konsentrasi substrat, sumber karbon, sumber nitrogen, vitamin dan asam amino (Bayoumi et al. 2007).

Nora (2004) mengemukakan bahwa amilase dan selulase semakin banyak digunakan sebagai bahan aditif pada makanan ternak. Tujuan utamanya adalah memperbaiki nutrisi ternak dengan cara mendegradasi kandungan seratnya, hal ini sangat penting bagi ternak berusia muda yang belum mempunyai kemampuan enzim dengan aktivitas tinggi untuk mengolah serat. Berdasarkan alasan komersial, amilase banyak digunakan sebagai food additive, sedangkan selulase mempunyai harga mahal sehingga jarang digunakan sebagai food additive. Dengan alasan ini maka sangat penting mencari sumber enzim termofilik dari bakteri air panas dan mengolahnya menjadi bahan pencampur makanan ternak.

Mikroorganisme termofilik memilih hidup pada temperatur yang tidak biasa ditemukan di alam, seperti di sumber air panas. Mikroorganisme ini tidak hanya mempunyai kemampuan hidup pada temperatur yang tinggi tetapi mereka tumbuh dengan subur di dalam air panas. Komponen sel atau protein dari mikroorganisme ini bersifat tahan panas dibandingkan mikroorganisme mesofil. Kemampuan mikroorganisme termofilik untuk hidup pada temperatur tinggi dan menghasilkan enzim ekstraseluler yang stabil memungkinkan rekayasa genetika untuk memproduksi enzim secara besar-besaran untuk aplikasi industri (Elnasser \& Maraqa 2007).

Mikroorganisme termofilik adalah mikroorganisme yang hidup optimal pada suhu antara $45^{\circ} \mathrm{C}$ dan $80^{\circ} \mathrm{C}$ sedangkan hipertermofilik adalah mikroorganisme yang hidup optimal pada temperatur diatas $80^{\circ} \mathrm{C}$. Mikroorganisme termofilik bisa diisolasi dari hampir semua lingkungan, seperti tanah, sumber air panas dan kompos. Sedangkan mikroorganisme hipertermofilik hanya bisa diisolasi dari lingkungan yang terus-menerus panas, seperti sumber air panas suhu tinggi yang dipengaruhi aktivitas gunung vulkanik dan daerah dasar laut dalam (Raven \& Johnson 2000)

Beberapa enzim yang bernilai komersial adalah; selulase, hemiselulase, xilanase, amilase, protease, fitase, dan lipase. Enzim-enzim yang digunakan dalam industri harus memenuhi syarat, yaitu aktif pada kondisi suhu dan pH tinggi karena pada umumnya proses dalam industri berlangsung pada $\mathrm{pH}$ dan suhu tinggi. Oleh karena itu pencarian isolat bakteri penghasil enzim yang aktif pada kondisi suhu dan $\mathrm{pH}$ tinggi merupakan salah satu usaha yang mempunyai prospek ekonomi tinggi (Puspaningsih, 2007). 
Oleh sebab itu peneliti tertarik untuk mengetahui enzim apa saja yang dihasilkan oleh Anoxybacillus sp yang merupakan bakteri air panas yang telah berhasil penulis identifikasi pada penelitian sebelumnya. Ternyata bakteri ini mempunyai zona bening yang besar pada substrat CMC dan pati. Hal inilah yang menjadi dasar penelitian selanjutnya, yaitu untuk melakukan purifikasi parsial enzim Anoxybacillus sp serta mengetahui kemampuannya untuk menghidrolisis limbah berserat.

\section{BAHAN DAN METODE}

Alat. Peralatan yang digunakan adalah: petridish, hoki stik, jarum ose, alat-alat gelas, inkubator, autoklaf pipet mikro, timbangan digital, water bath, chemical hood, pengaduk magnet, hotplate stirrer, tabung sentrifugasi, tabung mikro, alat elektroforesis (Mupid exu), perangkat dokumentasi, freezer, Thermal Cycler PCR system, mikrosentrifuga, mikrosentrifuga dingin, vortex, dan alatalat gelas laboratorium.

Bahan-bahan yang digunakan adalah: Agarose (Iwai AG 5994), Akuades, $\mathrm{HCl}, \mathrm{NaOH}$ (Merck), Bacto Agar (Himedia), Tryptone, Beef extract, $\mathrm{NaCl}$, Peptone, Yeast extract (Himedia), EDTA, Etanol pa (Merck), Etidium bromida, Sodium Dodesil Sulfat (SDS), Isopropanol, Tris base, Buffer TBE (Tris Boric acid EDTA) (Takara), Nutrient Broth, Nutrient Agar (Himedia), CTAB (Hexadecyltrimethyl ammonium Bromide), Gram staining solution dari Merck (larutan kristal violet, Safranin, lugol, larutan decolourizing), $\left(\mathrm{NH}_{4}\right)_{2} \mathrm{SO}_{4} 2 \mathrm{~g}, \mathrm{MgSO}_{4} .7 \mathrm{H}_{2} \mathrm{O} 0,2 \mathrm{~g} ; \mathrm{KH}_{2} \mathrm{PO}_{4}$ $14 \mathrm{~g} ; \mathrm{K}_{2} \mathrm{HPO}_{4} 6 \mathrm{~g}$; Trisodium sitrat $1,0 \mathrm{~g}$; inulin, susu skim, pati (Merck), CMC (Carboxymethil Cellulosa) (Merck), Congo red, TE (10 mM Tris-HCl, 1Mm EDTA, pH 7.6), Lysozyme $(60 \mathrm{mg} / \mathrm{mL})$, amonium sulfat, Tris- $\mathrm{HCl}$, Gliserin, akrilamida, amonium persulfat, NNNN-Tetrametilen Diamina (TEMED), Commasie blue, larutan destaining (5\% metanol dan $7 \%$ asam asetat), primer universal $8 \mathrm{~F}$ dan $1541 \mathrm{R}$ (Zainal 2009), dd $\mathrm{d}_{2} \mathrm{O}$ (DW), Deoksi Nucleotide Triposphate (dNTPs), taq polimerase, $10 \mathrm{x}$ bufer PCR.

Isolasi dan Identifikasi Bakteri Termofilik. Sampel air panas dikoleksi dari sumber air panas yang ada di Kabupaten Solok, yaitu Air Panas Bukit Kili Ketek yang berukuran $2 \mathrm{~m}$ x 1,5 m dengan menggunakan botol $10 \mathrm{~mL}$ beserta tutupnya dan dimasukkan ke dalam thermal containers (termos) untuk mempertahankan suhunya selama perjalanan ke laboratorium untuk analisa selanjutnya pada hari yang sama. Sampel diambil pada kedalaman $40 \mathrm{~cm}$ di bawah permukaan air, agak jauh dari pinggir. Suhu air panas pada saat diambil adalah $52^{\circ} \mathrm{C}$ dengan pH 8. Sampel diambil lebih dekat ke mata air agar dapat mewakili suhu yang paling tinggi di kolam air panas tersebut. Bakteri termofilik diisolasi, dikayakan dalam Nutrient Broth dan dimurnikan menggunakan metode gores pada media NA. Suhu inkubasi yang digunakan adalah $52^{\circ} \mathrm{C}$ selama 24 jam (Nunes \& Martin 2001).

Isolat bakteri terpilih diidentifikasi dengan menggunakan analisis gen 16S rRNA. Amplifikasi DNA dengan PCR serta pengolahan data sekuensing DNA dengan software Clustal W (Zona 2011).

Uji Amilase. Hidrolisis pati diuji di dalam medium nutrient agar yang mengandung $1 \%$ pati. Plate diinkubasi pada suhu $52^{\circ} \mathrm{C}$ selama 24 jam. Adanya daerah bening disekitar koloni setelah penambahan Lugol iodin menunjukkan bahwa adanya aktivitas amilase (Elnasser \& Maraqa 2007).

Uji Hidrolisis Karboksimetil Selulosa (CMCase/ Selulase). Untuk menentukan selulosa ekstraseluler ditentukan di dalam medium thermus agar plate $(0,5 \% \mathrm{NaCl}$, $0,5 \%$ pepton, $0,4 \%$ beef extract, $0,2 \%$ yeast extract, dan $2 \%$ agar) yang mengandung $0,5 \%(\mathrm{w} / \mathrm{v})$ karboksimetilselulosa (pH 6,5). Kultur diinkubasi 24 jam pada suhu $52^{\circ} \mathrm{C}$. Aktivitas selulase dideteksi dengan Congo red 0,1\% dan $\mathrm{NaCl} 1 \mathrm{M}$. Daerah bening di sekeliling bakteri yang tumbuh yang berlatar merah menunjukkan hasil yang positif (Elnasser \& Maraqa 2007)

Pemekatan Protein Bakteri Termofilik. Kultur bakteri dalam $100 \mathrm{~mL}$ Nutirient Broth yang mengandung $0,1 \% \mathrm{CMC}$ dan $0,1 \%$ pati diinkubasi pada suhu $55^{\circ} \mathrm{C}$ selama 24 jam. Kultur disentrifugasi 10.000 rpm selama 10 menit pada suhu $4^{\circ} \mathrm{C}$. Supernatan dipresipitasi dengan $80 \%$ amonium sulfat. Amonium sulfat ditambahkan 1 sendok spatula tiap 5 menit dan larutan diaduk pelan. Setelah amonium sulfat habis, campuran didiamkan semalam. Kemudian sampel didialisis semalam dengan bufer dialisis (128 mL NaCl, $80 \mathrm{~mL}$ Tris- $\mathrm{HCl}$ dan $80 \mathrm{~mL}$ gliserin) dengan 
dua kali penggantian bufer. Sampel hasil dialisis dimasukkan ke dalam tabung mikro dan disimpan pada $20^{\circ} \mathrm{C}$ untuk kemudian menjadi sampel SDS-PAGE (Skowronek et al. 2005).

SDS-PAGE (Sodium Dodecyl Sulphate Polyacrylamide Gel Electrophoresis). SDS- PAGE dilakukan dengan menggunakan dua macam gel, yaitu separating gel $8 \%$ dan stacking gel 3,9\%. Komposisi separating gel adalah $3965 \mu \mathrm{L} \mathrm{dH}_{2} \mathrm{O}, 1500 \mu \mathrm{L} 1,5$ Tris $4 \mathrm{x}$ Tris $\mathrm{HCl} 1,5 \mathrm{M}$ yang mengandung SDS ( $\mathrm{pH} 8,8), 2000 \mu \mathrm{L}$ akrilamida 30\%, $50 \mu \mathrm{LAPS}$ dan $10 \mu \mathrm{L}$ TEMED Komposisi stacking gel adalah $1525 \mu \mathrm{L} \mathrm{dH_{2 }} \mathrm{O}, 625 \mu \mathrm{L} 0,5$ Tris yang mengandung $0,4 \%$ SDS (pH 6,8), $325 \mu \mathrm{L}$ akrilamida $30 \%$, $12,5 \mu \mathrm{L}$ APS, dan 2,5 $\mu \mathrm{L}$ TEMED. Separating gel dimasukkan ke dalam gel tray dengan pipet mikro $1 \mathrm{~mL}$, diratakan dengan $\mathrm{H}_{2} \mathrm{O}$ dan dibiarkan 30 menit. Stacking gel dimasukkan ke dalam gel tray dan dipasang sisir (comb), kemudian tray dimasukkan ke dalam cast gel SDS PAGE. Buffer running ditambahkan ke dalam cetakan, kemudian dimasukkan penanda protein dan sampel. Sampel dielektroforesis selama 60 menit dengan voltase $30 \mathrm{~mA}$. Setelah selesai elektroforesis, ditambah commasie blue pada gel dan direndam selama 4 jam. Gel dicuci dengan larutan destainning untuk kemudian difoto (scanning) (Sambrook et al. 1989).

\section{Aplikasi Ekstrak Enzim Kasar untuk} Menghidrolisis Limbah Berserat. Dibuat larutan standar

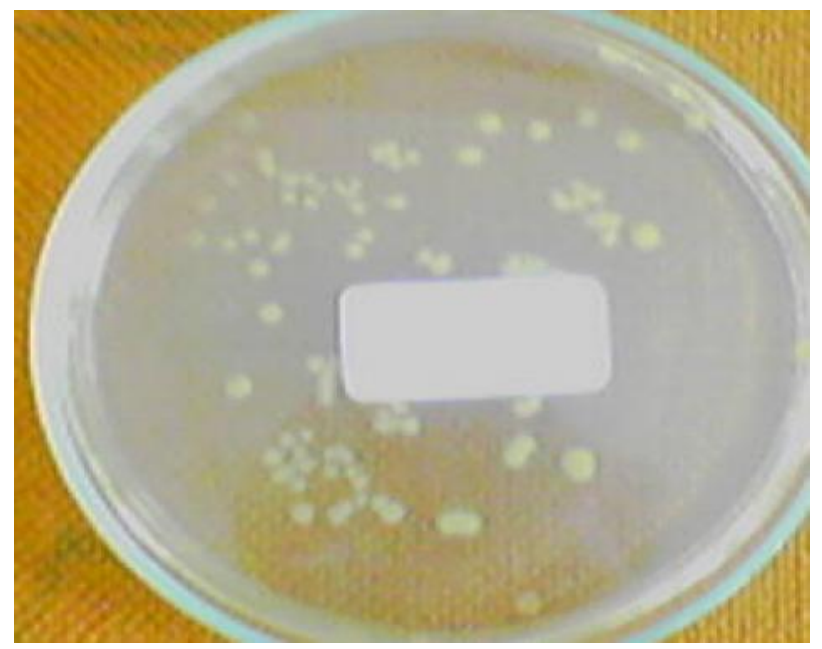

(a)

Gambar 1 Bentuk koloni bakteri air panas pada pengenceran $10^{-4}$ (A) dan $10^{-5}$ (B) induk glukosa $1 \mathrm{mg} / \mathrm{mL}$ dan diencerkan untuk membuat deret standar glukosa dengan konsentrasi 0,$1 ; 0,15 ; 0,20$; 0,25; 0,30;0,35 mg/mL. Masing-masing $2 \mathrm{~mL}$ standar dimasukkan kedalam tabung reaksi dan ditambahkan $2 \mathrm{~mL}$ asam fenol sulfat. Didiamkan selama 30 menit, kemudian dimasukkan ke dalam penangas air mendidih selama 15 menit. setelah itu didinginkan pada permukaan es batu. Absorban standar diukur dengan spektrofotometer pada panjang gelombang $540 \mathrm{~nm}$. Setelah itu dibuat kurva standar.

Analisis Aktivitas Enzim Selulase. Sebanyak 0,5 mL enzim selulase dicampurkan dengan $1 \mathrm{~mL} \mathrm{CMC} 1 \%$ dan 1 $\mathrm{mL}$ bufer $\mathrm{pH}$ (divortex), kemudian diinkubasi pada suhu $50^{\circ} \mathrm{C}$ selama 30 menit. Kemudian ditambahkan $2 \mathrm{~mL}$ asam fenol sulfat, dipanaskan dalam air mendidih selama 15 menit. Setelah dingin, diukur jumLah gula pereduksi yang dibebaskan dengan spektrofotometer pada $\lambda=540 \mathrm{~nm}$. Pada pengukuran ini juga dilakukan hal yang sama terhadap kontrol (enzim yang langsung diinaktivasi dengan asam fenol sulfat) dan blanko (bufer fosfat). Pengukuran aktivitas enzim juga diujikan pada sampel limbah berserat yaitu limbah tebu dan nenas.

\section{HASIL DAN PEMBAHASAN}

Isolasi Bakteri Termofilik. Air diambil sebagai sampel dari sumber air panas Bukit Kili Ketek di Kabupaten Solok. Suhu air panas adalah $52^{\circ} \mathrm{C}$ dan $\mathrm{pH}$ air diukur dengan indikator universal dalah 8. Pengambilan sampel diambil

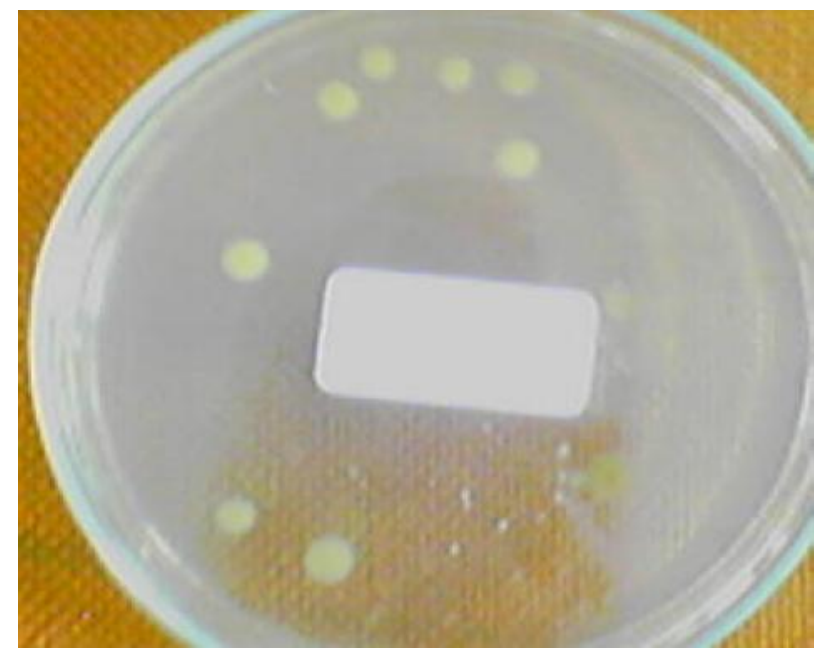

(b) 


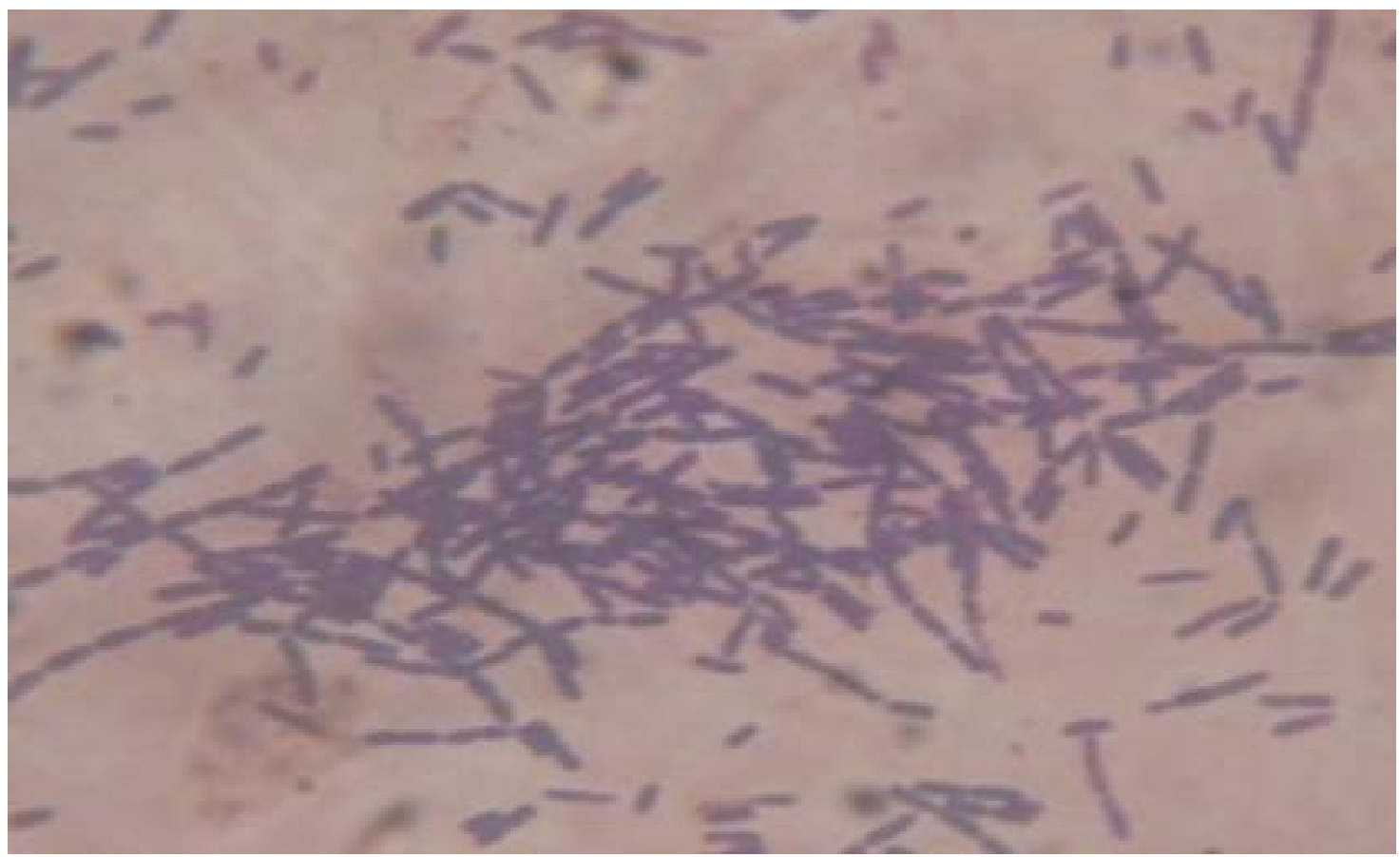

Gambar 2 Foto pewarnaan Gram bakteri air panas Anoxybacillus sp.

mendekati mata air, yaitu yang mempunyai suhu paling tinggi pada kolam air panas sewaktu pengambilan sampel. Hal ini bertujuan untuk mendapatkan bakteri yang hidup disekitar mata air panas dan mempunyai aktivitas enzimatis pada suhu yang tertinggi dalam kolam air panas.

Pada Gambar 1, terlihat koloni bakteri air panas yang sudah tumbuh terpisah dengan baik. Bentuk koloni bulat, ukuran bervariasi, berwarna putih, dan ada yang putih kekuningan. Hasil pewarnaan Gram menunjukkan bahwa sebagian besar bakteri air panas dari Air Panas Bukit Kili Ketek ini adalah jenis bakteri streptobacilli (basilus) Gram positif, hanya dua isolat yang merupakan Gram negatif. Salah satu isolat air panas S2A jenis basilus, Gram positif dari hasil pewarnaan Gram bakteri yang berwarna ungu ada pada Gambar 2. Pewarnaan Gram pada bakteri didasarkan pada tebal atau tipisnya lapisan peptidoglikan di dinding sel dan banyak sedikitnya lapisan lemak pada membran sel bakteri. Bakteri Gram positif memiliki dinding sel yang tebal dan membran sel selapis serta tidak memiliki membran luar (outer membrane). Sedangkan bakteri Gram negatif mempunyai dinding sel tipis yang berada diantara dua lapis membran sel.

\section{Penapisan akteri Penghasil Enzim Ekstraseluler.} Pada saat semua isolat bakteri ditumbuhkan dalam medium nutrient starch agar, hanya 7 isolat yang tumbuh dengan menghasilkan zona bening setelah disiram larutan iodin, yaitu S1A, S2A, S4A, S5A, S6A, 48A, dan 48B. Hal ini menunjukkan bahwa 7 isolat tersebut menghasilkan enzim ekstraseluler amilase (Gambar 3). Isolat S1A dan S2A menghasilkan indeks zona bening amilase paling tinggi, yaitu 2,5 mm. Molekul pati terdiri dari polimer glukosa yang dihubungkan oleh ikatan $\alpha-1,4$ dan kadang-kadang mempunyai ikatan $\alpha-1,6$ ikatan tersebut dapat dihidrolisis oleh amilase untuk menghasilkan dekstrin, glukosa, dan maltosa. Larutan iodin bisa digunakan sebagai indikator ada tidaknya molekul pati karena iodin akan membentuk kompleks berwarna biru kehitaman dengan pati. Munculnya zona bening di sekitar koloni bakteri karena molekul pati telah dipecah oleh amilase sehingga larutan iodin tidak membentuk kompleks lagi dengan pati.

Semua isolat bakteri yang ditanam dalam medium CMC menunjukkan aktivitas selulase, karena munculnya zona bening di sekitar koloni bakteri setelah plate disiram dengan congo red dan dicuci dengan $\mathrm{NaCl} 1 \mathrm{M}$ 


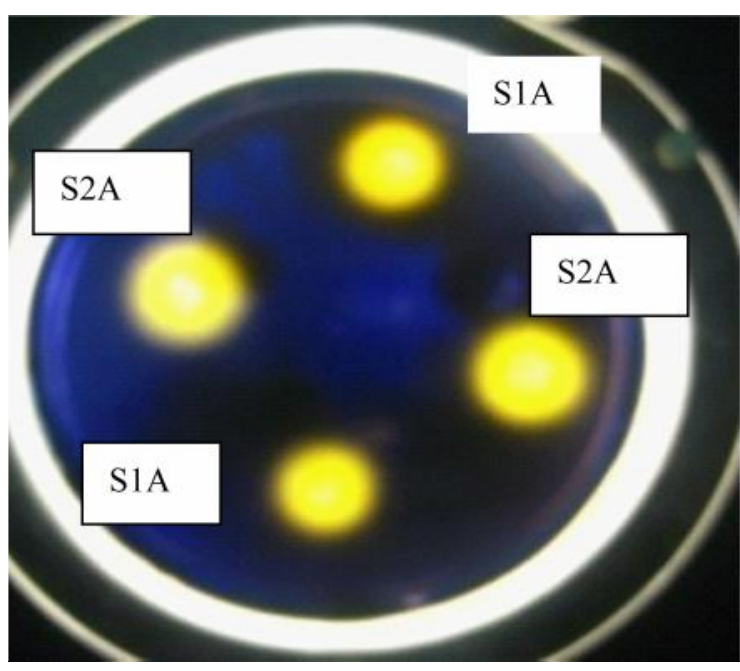

(a)

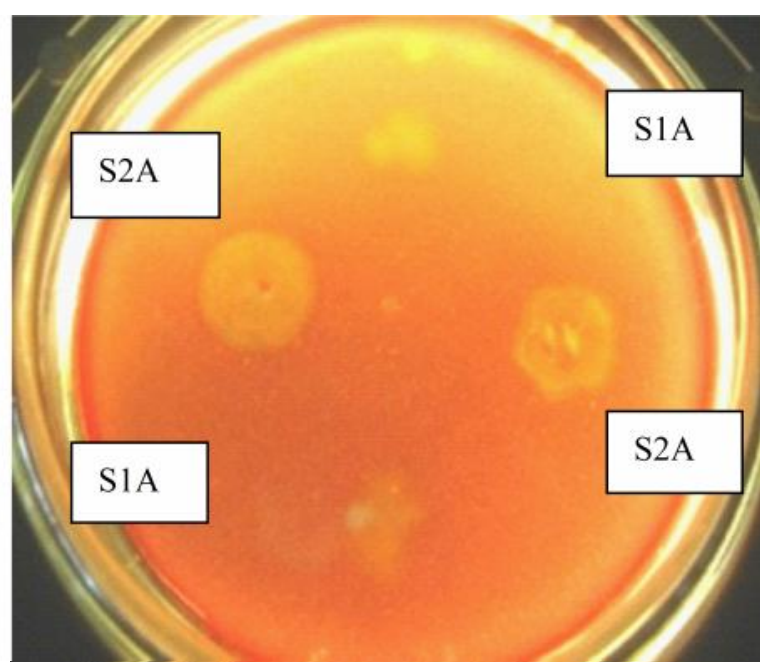

(b)

Gambar 3 Isolasi bakteri termofilik Anoxybacillus sp. penghasil amilase (A) dan (B) selulase yang diinkubasi pada suhu $52^{\circ} \mathrm{C}$ selama 24 jam

(Gambar 3). Congo red dapat dijadikan sebagai indikator adanya selulosa karena dapat berikatan secara nonkovalen dengan serat selulosa (Abdelnasser \& Ahmed 2007).

Selulase adalah enzim yang dapat menghidrolisis selulosa. Homopolimer selulosa disusun oleh anhydro-Dglucosa yang dihubungkan oleh ikatan $\beta-1,4$ dan merupakan biopolimer yang paling banyak di alam. Degradasi selulosa menjadi glukosa membutuhkan gabungan atau aksi kerjasama 3 enzim, yaitu; endo-1,4ßglukanase, ekso-1,4ß-glukanase, dan ß-glukosidase. CMC (Carboxymethyl cellulose) adalah substrat untuk mengetahui aksi enzim endo-1,4ß-glukanase (Bhat \& Bhat 1997). Oleh karena itu, bakteri yang menghasilkan zona bening pada medium CMC tersebut menghasilkan enzim endo-1,4ß-glukanase (CMCase). S2A adalah isolat yang mempunyai aktifitas selulase paling tinggi dibandingkan dari 7 isolat yang lain karena mempunyai indeks zona bening selulase lebih tinggi yaitu 2,6 mm.

Dari hasil uji dengan CMC menunjukkan bahwa semua isolat bakteri yang berhasil diisolasi mempunyai kemampuan menghasilkan selulase. Hal inilah yang menjadi alasan penelitian selanjutnya yaitu untuk mencari isolat bakteri yang mempunyai aktivitas selulase paling tinggi.

Di samping itu, isolat S2A juga menghasilkan amilase tinggi dengan indeks zona bening amilase 2,5 mm. Setelah diidentifikasi dengan menggunakan analisis gen 16S rRNA serta pengolahan data sekuensing DNA dengan menggunakan software Clustal $\mathrm{W}$ diperoleh data isolat bakteri (S2A) ini mempunyai kemiripan 97\% dengan Anoxybacillus sp.

\section{Pemekatan Protein Ekstraseluler Isolat Bakteri Air} Panas Anoxybacillus sp. Isolasi protein isolat Anoxybacillus sp. dilakukan dengan cara presipitasi supernatan kultur dengan amonium sulfat $80 \%$ (Scopes1987). Pada prinsipnya, penambahan amonium sulfat sedikit demi sedikit sampai jenuh bertujuan untuk mengendapkan protein yang terdapat pada larutan ekstrak kasar enzim (supernatan). Karena enzim adalah protein maka pengendapan akan menyebabkan konsentrasi protein dalam larutan semakin tinggi, pada saat ini juga konsentrasi garam dalam larutan juga tinggi (salting in). Penambahan garam tertentu akan menyebabkan kelarutan protein berkurang (salting out). Molekul air berikatan dengan ionion garam akan semakin banyak, hal ini akan mengakibatkan penarikan selubung air yang mengikat protein. Protein akan lepas dari air, saling berinteraksi, beragregasi dan kemudian mengendap.

Proses isolasi enzim selanjutnya adalah dialisis (Smith1984), proses ini bertujuan untuk menghilangkan kadar garam yang tersisa dari proses pengendapan dengan amonium sulfat. Proses ini menggunakan membran dialisis 
yang memisahkan antara sampel dengan larutan bufer, sisasisa garam akan keluar dari kantung membran menuju larutan bufer sehingga bufer akan menjadi keruh.

Hasil pengendapan protein (enzim) setelah dialisis dapat diketahui dengan menggunakan teknik Sodium Dodecyl Sulphate Polyacrylamide Gel Electrophoresis (SDS-PAGE). Prinsip analisis SDS-PAGE adalah pemisahan protein berdasarkan ukuran molekul. Gel disusun oleh akrilamida dan N,N-metilen-bis-akrilamida yang berpolimerisasi melalui mekanisme radikal bebas dengan bantuan katalisator N,N,N,N-tetrametilen diamina (TEMED) dan inisiator amonium persulfat (APS) (Sambrook1989).

Deterjen ionik (SDS) akan bereaksi dengan protein dan membentuk kompleks yang mengandung muatan negatif, sehingga pergerakan protein dalam medan listrik hanya didasarkan pada ukuran molekul. Protein yang berukuran kecil akan lebih cepat dibandingkan protein berukuran besar. Berat molekul protein kemudian diukur dengan menggunakan protein standar yang telah diketahui berat molekulnya. Pada isolasi protein isolat air panas Anoxybacillus sp. ini, gel yang telah diwarnai dengan coomassie blue memperlihatkan banyak pita. Pita-pita

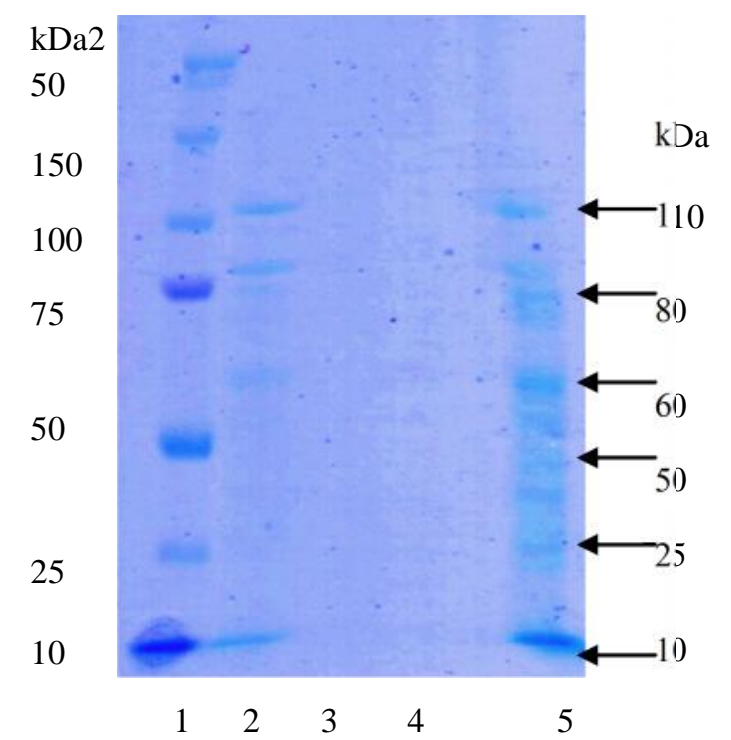

Gambar 4 SDS PAGE Ekstrak Enzim Isolat Bakteri Air Panas Anoxybacillus sp. (1. penanda; 2. supernatan Anoxybacillus sp.; 3. supernatan yang ditambah amonium sulfat; 4. Kosong; 5. supernatan Anoxybacillus sp. hasil dialisis) tersebut menggambarkan banyaknya protein atau enzim ekstraseluler yang dihasilkan oleh bakteri dan telah berhasil diendapkan.

Dari hasil SDS-PAGE (Gambar 4), diperoleh 4 pita pada supernatan Anoxybacillus sp. (kolom 2 pada Gambar 4) yaitu pita 1 berukuran $\pm 110 \mathrm{kDa}$, pita 2 berukuran $\pm 80 \mathrm{kDa}$, pita 3 dengan hasil yang sangat tipis tapi masih bisa dibedakan berukuran $\pm 60 \mathrm{kDa}$ dan pita 4 berukuran \pm 10 kDa. Pada sampel supernatan ditambah amonium sulfat tidak muncul pita. Tidak munculnya pita protein pada supernatan setelah ditambah amonium sulfat (kolom 3 pada Gambar 4) karena protein tercampur dengan garam amonium sulfat sehingga reaksi antara commasie blue dengan protein tidak lebih optimal. Sisa amonium sulfat yang ada dalam larutan enzim dibuang dengan proses dialisis. Sampel hasil dialisis (kolom 5 pada Gambar 4) menghasilkan banyak pita, pita dengan ukuran $\pm 110 \mathrm{kDa}$, $\pm 80 \mathrm{kDa}, \pm 60 \mathrm{kDa}, 50 \mathrm{kDa}, 25 \mathrm{kDa}$, dan $\pm 10 \mathrm{kDa}$ terlihat makin jelas. Munculnya banyak pita pada hasil dialisis karena protein atau enzim yang ada dalam larutan semakin pekat dengan adanya proses presipitasi dengan amonium sulfat. Pengendapan protein enzim dengan amonium sulfat adalah langkah awal untuk memurnikan protein enzim. Pita-pita yang muncul ini merupakan enzim ekstraseluler yang dihasilkan oleh bakteri air panas Anoxybacillus sp. Banyaknya pita yang muncul menunjukkan bahwa enzim ekstraselular yang dihasilkan juga mempunyai ukuran molekul yang berbeda-beda. Pada penelitian ini tidak dilakukan proses pemurnian enzim, oleh sebab itu pitapita yang muncul tersebut hanya dapat dibahas dengan merujuk kepada penelitian yang telah dilaporkan sebelumnya.

Pita yang berukuran $80 \mathrm{kDa}$ diperkirakan adalah selulase. Salah satu selulase yang dihasilkan oleh Bacillus pumilus adalah CMCase. Enzim ini dipresipitasi dengan $80 \%$ amonium sulfat dan dimurnikan dengan kolom kromatografi. Hasil SDS-PAGE yang diperoleh adalah pita berukuran $80 \mathrm{kDa}$ (Kotchoni 2006). Enzim yang dimurnikan dari isolat $T$ aurantiacus $s p$ menghasilkan berat molekul berkisar $25 \mathrm{kDa}$ dan $80 \mathrm{kDa}$. Supernatan kultur dipresipitasi dengan $80 \%$ amonium sulfat dan dimurnikan dengan kolom kromatografi. Hasil pemurnian enzim menunjukkan bahwa 
pita $24 \mathrm{kDa}$ dan $80 \mathrm{kDa}$ adalah ß-glukosidase dan selulase (Tong 1980). Sedangkan pita pada $60 \mathrm{kDa}$ diperkirakan adalah amilase. Pita á-amilase dengan ukuran $62 \mathrm{kDa}$ diperoleh dari isolat Geobacillus thermoleoverans $\mathrm{YN}$ pada suhu $55^{\circ} \mathrm{C}$ (Mahmoud et al 2007). Kohji dan kawankawan (1999) juga melaporkan bahwa $\alpha$-amilase dari isolat Bacillus subtilis muncul pada $67 \mathrm{kDa}$ setelah dilakukan pemurnian enzimnya. Selain itu Haruyuki dan kawan-kawan (1996) juga melaporkan hasil penelitiannya tentang $\alpha$ amilase termostabil yang dimurnikan dari Cryptococcus sp. mempunyai ukuran $67 \mathrm{kDa}$.

Pada penelitian ini juga ditemukan pita sekitar $62 \mathrm{kDa}$, ada kemungkinan pita tersebut adalah amilase. Pita $110 \mathrm{kDa}$ pada hasil SDS-PAGE isolat bakteri air panas Anoxybacillus sp. kemungkinan adalah aminopeptidase. Berdasarkan hasil penelitian Etsuo dan kawan-kawan (1988) yang melakukan karakterisasi aminopeptidase dari Thermus aquaticus YT-1 dengan ukuran molekul 108 kDa. Satyanarayana dan kawan-kawan (2004) melaporkan pitapita disekitar $42 \mathrm{kDa}$ dan $48 \mathrm{kDa}$ adalah enzim glukoamilase yang dieksresikan oleh bakteri termofilik dan mempunyai peran penting dalam proses starch saccharification.

Aplikasi Ekstrak Enzim Kasar Anoxybacillus sp. untuk Menghidrolisis Limbah Berserat. Hasil ekstraksi enzim selulase yang dihasilkan oleh bakteri Anoxybacillus sp. diaplikasikan untuk menghidrolisis limbah tebu dan nenas. Limbah tebu dan nenas ini mempunyai potensi untuk pakan ternak karena kandungan karbohidratnya masih banyak, salah satunya adalah selulosa. Selulosa dapat dipecah menjadi molekul sederhana melalui hidrolisis dengan bantuan enzim selulase.

Aktivitas enzim diukur dengan metode asam fenol sulfat. Uji aktifitas selulase menggunakan enzim aktif untuk sampel, enzim inaktif sebagai kontrol, dan bufer fosfat sebagai blanko. Nilai aktifitas enzim mempengaruhi kadar gula pereduksi yang dihasilkan. Semakin tinggi aktivitas enzim semakin tinggi pula gula pereduksi yang dihasilkan. Hal ini disebabkan oleh kerja enzim selulase yang memutuskan ikatan glikosidik pada selulosa menjadi glukosa (di mana selulosa adalah polimer dengan monomernya selobiosa yang merupakan gabungan dari dua unit glukosa) (Kamara et al. 2011).
Aktifitas enzim selulase paling tinggi adalah $0,451 \mathrm{IU} / \mathrm{mL}$ terhadap ampas tebu dan $0,310 \mathrm{IU} / \mathrm{mL}$ terhadap ampas nenas. Suhu optimalnya adalah $50^{\circ} \mathrm{C}$ pada $\mathrm{pH} 6$. Satu unit aktifitas enzim dinyatakan sebagai jumlah mikromol glukosa yang dihasilkan oleh $1 \mathrm{~mL}$ enzim setiap menit.

\section{SIMPULAN}

Hasil purifikasi parsial ekstrak enzim kasar bakteri air panas Anoxybacillus sp. yang telah dipekatkan dengan $80 \%$ amonium sulfat dan didialisis menghasilkan pita protein dengan ukuran $\pm 110 \mathrm{kDa}, \pm 80 \mathrm{kDa}, \pm 75 \mathrm{kDa}, \pm 60$ $\mathrm{kDa}, \pm 50 \mathrm{kDa}, \pm 40 \mathrm{kDa}, \pm 25 \mathrm{kDa}$, dan $\pm 10 \mathrm{kDa}$. Anoxybacillus sp. mempunyai ekstrak enzim kasar selulase. Aktifitas enzim selulase paling tinggi adalah 0,451 IU/mL terhadap ampas tebu dan $0,310 \mathrm{IU} / \mathrm{mL}$ terhadap ampas nenas.

\section{UCAPAN TERIMAKASIH}

Terima kasih banyak diucapkan kepada Prof. Dr. Sumaryati Syukur, MSc dan Prof. Drh. Hj. Endang Purwati, PhD serta lembaga Penelitian dan Pengabdian Masyarakat UIN SUSKA Riau. Terima kasih juga disampaikan kepada kepala laboratorium LIPI Bogor, laboratorium THT UNAND serta Laboratorium PEM UIN SUSKA RIAU.

\section{DAFTAR PUSTAKA}

Abdelnasser \& Ahmed. 2007. Isolation and identification of new cellulases producing thermophilic bacteria from an egyptian hot springs and some properties of the crude enzyme. Australian Journal of Basic and Applied Science 1(4): 473-478.

Bayoumi, Ra \& Loubodey. 2007. Production, purification and characterization of thermophilic lipase for application in bio-detergent industry. Journal of Applied Sciences Research 3(12): 1752-1765.

Bhat, M.K \& Bhat, S. 1997. Cellulose degrading enzymes and their potential industrial application. Biotechnol. Adv 15: 583-620.

Etsuo, Shuichi, Hiroshi, Takisha \& Kunio 1988. Isolation and characterization of a thermostable aminopeptidase from Thermus aquaticus YT-1, an extremely thermophilic bacterium. Agric. Biol. Chem 52(7): 17551763. 
EInasser Ziad \& Maraqa, A. 2007. Isolation and characterization of new thermophilicbacteria in jordan. The Internet Journal of Microbiology Vol 3. No. 2.

Hariyuki, Mariko, Miyosi \& Yuzuru. 1996. Raw starch digesting and thermostable $\alpha$-amylase from yeast cryptococcus sp. purification, characterization and sequencing. Biochemistry Journal 318: 989-996.

Kamara, Saadah \& Gaffar. 2007. Degradasi enzimatik selulosa dari batang pohon pisang untuk produksi glukosa dengan bantuan aktivitas selulolitik trichoderma viridae. Bandung: Lembaga Penelitian UNPAD.

Kohji, Takashi \& Hiroky. 1999. Characteristics of two forms of a-amylases and structural implication. Applied and Environmental Microbiology 65(10): 4652-4658 .

Kotchoni, Gachomo, Omafuvbe \& Shonukan. 2006. Purification and biochemical characterization of carboxymethyl cellulase (cmcase) from a catabolite repression insensitive mutant of bacillus pimilus. International Journal of Agriculture and Biology 08(2): 286-292.

Mahmoud M. Berekaa, Nadia A. Soliman, Yasser R. AbdelFattah. 2007. Production, partial characterization and cloning of thermostable $\alpha$-amylase of a thermophile geobacillus thermoleovorans yn. Biotechnology 6: 175183.

Narayan, Vinay \& Mohammed 2008. Isolation and characterization of aerobic thermophilic bacteria from the savusavu hot spring in fiji. Microbes and Environment 23(4): 350-352.

Nora. S et al. 2004. Cellulase fermentation an a novel substrate and subsequent utilization of home-produced cellulase and commercial amylase i rabbit feeding trial. Science Direct 20(1): 49-57.
Nunes. A \& Martin. 2001. Isolation, properties and kinetics of growth of thermophilic bacillus. Brazillian Journal of Microbiology 32: 271-275.

Puspaningsih, N. 2007. Enzim fibrolitik: manfaat dan prospek pengembangannya. Surabaya: FMIPA-UNAIR.

Raven, Jhonson \& Brown, J. 2009. Primitive Thermophilic Bacteria. MB 451. Microbial Diversity. Department of Microbiology. NC State University.

Sambrook. J, Fritsch \& Maniatis. 1989. Molecular Cloning. A Laboratory Manual.Edisi Kedua. Cold Spring Harbor Laboratory Press.

Scopes RK,1987. Protein Purification Principles and Practice. Edisi ke-2. New York: SpringerVerlag.

Skowronek. Marcin, Fiedurek. Jan. 2005. Purification and properties of extracellular endoinulinase from aspergillus niger 20 osm. Food Technol. Biotechnol 44(1): 53-58.

Smith, B.J. 1984. SDS polyacrylamide gel electrophoresis of proteins. Methoda in Molecular Biology 1: 41-55.

Satyanarayana, Noorwez, Kumar, Rao, Ezhiluannam \& Kaur. 2004. Development of an ideal starch saccharification process using amylolitic enzymes from thermophiles. Biochemical Society Transaction 32(2): 276-278.

Tong \& Maxwell. 1980. Purification and properties of the cellulases from thermophilic fungus thermoascus aurantiacus. Biochemical Journal 191: 83-94.

Zona. 2011. Skrining dan identifikasi bakteri termofilik penghasil selulase dan amilase dari sumber air panas bukit kili solok sumatera barat dengan analisis gen $16 \mathrm{~s}$ rRNA. Jurnal Photon 2(1): 37-44. 